\title{
Calix[4]arene Chalcone Amides as Effectors of Mitochondria Membrane Polarization
}

\author{
S. G. Shlykov ${ }^{1}$, A. V. Sylenko ${ }^{1}$, L. G. Babich ${ }^{1}$, S. O. Karakhim ${ }^{1}$, \\ O. Yu. Chunikhin ${ }^{1}$, O. A. Yesypenko ${ }^{2}$, V. I. Kal'chenko', \\ and S. O. Kosterin ${ }^{1}$
}

${ }^{1}$ O. V. Palladin Institute of Biochemistry, N.A.S. of Ukraine, 9, Leontovych Str., UA-01030 Kyiv, Ukraine

${ }^{2}$ Institute of Organic Chemistry, N.A.S. of Ukraine, 5, Murmans'ka Str., UA-02660 Kyiv, Ukraine

Calixarenes are supramolecular compounds with a unique three-dimensional structure, the biological activity of which is determined by the chemical groups on the upper or lower rim. As shown in the previous works, using isolated mitochondria and digitonin-permeabilized myometrium cells, the calix[4]arene chalcone amides modulated the levels of both mitochondria-membrane polarization and $\mathrm{Ca}^{2+}$ concentration in the myometrial mitochondria matrix. As shown, the incubation of the mitochondria with calix[4]arene chalcone amides is accompanied by changes of the average hydrodynamic diameter of mitochondria. The aims of this study are as follow: to investigate the kinetics of the mitochondria diameter changes under the effects of calix[4]arenes with two and four chalcone amide groups; find out whether or not calix [4]arene chalcone amides penetrate into the cell and whether the polarization of the mitochondria membranes undergoes alterations at the incubation of the primary myometrium-cells' culture with these compounds. Experiments are conducted on two biochemical models: isolated myometrial mitochondria and primary myometrium-cells' culture. The hydrodynamic diameter of mitochondria is investigated using the dynamic light-scattering method with the use of a laser correlation spectrometer Malvern Instruments 'ZetaSizer-3' (United Kingdom). Polarization of mitochondria membranes is investigated using confocal laser scanning microscope LSM 510 META Carl Zeiss. The calix[4]arene chalcone amide C-1070 fluorescence spectrum is studied using the QuantaMaster ${ }^{\mathrm{TM}} 40$ spectrofluorimeter (Photon Technology International). As shown: the hydrodynamic diameter of the mitochondria depends on the composition of the incubation medium, and in the presence of ATP, it is smaller than in its absence; the hydrodynamic diameter of the mitochondria increases in time at the incu- 
bation of mitochondria with calix[4]arene chalcone amides; calix[4]arene chalcone amides' effect on the hydrodynamic diameter of the mitochondria increases with an increase in the number of chalcone amide groups in the structure of calix[4]arenes; calix[4]arene chalcone amides' effect on the hydrodynamic diameter of the mitochondria depends on the composition of the incubation medium, and at the presence of ATP, it is smaller than at its absence. Using calix[4]arene chalcone amide C-1070 (as fluorescent equivalent of C-1011), it is proved that these compounds penetrate the myometrial cells. The modulatory effects of calix[4]arene chalcone amide with two chalcone amide groups on the polarization of the mitochondria membranes is shown using primary myometrium-cell culture and potential-sensitive probe JC-1. Medical statistics indicate that uterine fibroids are widespread pathology. The search for compounds, which can reduce the volume of the tumour, is extremely important. The results allow suggest that calix[4]arene chalcone amides are promising compounds in the further study of their effect on the viability of the undesirable cells due to the launch of apoptosis of mitochondrial pathway.

Каліксарени - це макроциклічні молекули з унікальною тривимірною структурою, біологічна активність яких визначається хемічними групами на верхньому або нижньому вінці. У попередніх роботах з використанням фракції мітохондрій і перфорованих дигітоніном клітин міометрія було показано, що калікс[4]аренхалконаміди модулюють поляризацію мембран мітохондрій і рівень йонізованого Са у матриксі мітохондрій міометрія. Встановлено, що інкубація мітохондрій з калікс[4]аренхалконамідами супроводжується змінами середнього гідродинамічного діяметра мітохондрій. Метою даної роботи є: дослідити кінетику змін діяметра мітохондрій під впливом калікс[4]аренхалконамідів з двома та чотирма халконовими групами; з'ясувати, чи проникають калікс[4]аренхалконаміди у середину клітини та чи зазнає змін рівень поляризації мембран мітохондрій за інкубації первинної культури клітин міометрія з цими сполуками. Досліди проводяться на двох біохемічних моделях - на ізольованих мітохондріях міометрія та первинній культурі клітин міометрія. Функція розподілу мітохондрій за розміром визначається методою динамічного розсіювання світла за допомогою лазерного кореляційного спектрометра Malvern Instruments 'ZetaSizer-3' (Великобританія). Мембранний потенціял мітохондрій досліджується із використанням конфокального лазерного сканувального мікроскопа LSM 510 META Carl Zeiss. Спектер флюоресценції калікс[4]аренхалконаміду C-1070 визначається на спектрофлюориметрі QuantaMasterTM 40 компанії Photon Technology International. Одержані результати вказують на наступне: гідродинамічний діяметер мітохондрій залежить від складу середовища інкубації, і за наявности АТР він менший, ніж за ії відсутности; гідродинамічний діяметер мітохондрій збільшується у часі за інкубації мітохондрій з калікс[4]аренхалконамідами; вплив калікс[4]аренхалконамідів на гідродинамічний діяметер мітохондрій збільшується зі збільшенням кількости халконових залишків у структурі калікс[4]арену; вплив калікс[4]аренхалконамідів на гідродинамічний діяметер мітохондрій залежить від складу середовища інкубації, і за наявности АТP він менший, ніж за ї̈ відсутности. 3 використанням калікс[4]аренхалконаміду C-1070 (флюо- 
ресцентного аналогу C-1011) доведено, що ці сполуки проникають у клітини міометрія. На первинній культурі клітин міометрія та з використанням потенціялочутливого зонда JC-1 показано модулювальний вплив калікс[4]аренхалконаміду з двома халконовими групами на поляризацію мембран мітохондрій. Медична статистика свідчить, що міома матки є широко розповсюдженою патологією. Пошук сполук, здатних зменшити об’єм пухлини, є вкрай важливим. Одержані нами результати свідчать про те, що калікс[4]аренхалконаміди є перспективними сполуками у подальшому дослідженні їхнього впливу на життєздатність небажаних клітин через запуск апоптозу за мітохондрійним шляхом.

Key words: calixarenes, mitochondria membrane potential, myometrium.

Ключові слова: каліксарени, мембранний потенціял мітохондрій, міометрій.

(Received 4 December, 2019)

\section{INTRODUCTION}

Calixarenes are supramolecular compounds with a unique threedimensional structure, which have a biological activity determined by the chemical groups on the upper or lower rims. Calixarenes are widely investigated in bioorganic chemistry and biochemistry $[1,2,3,4]$. Due to its hydrophobic features, they are able to dissolve in cell lipids, which make them an important biologically active compounds carrier. Besides, it is possible to bind to the calixarenes functionally active groups in various amounts. One of these groups can be flavonoids, which have a wide range of biological activities $[5,6,7,8,9]$.

In the previous works, using mitochondria fraction and myometrium cells perforated with digitonin, we have shown that calix[4]arene chalcone amides are able to influence both the level of membrane polarization of mitochondria membrane [10] and the level of $\mathrm{Ca}^{2+}$ concentration in the myometrial mitochondria matrix [10]. It was also studied that the incubation of mitochondria with calix[4]arene chalcone amides for 5 minutes was accompanied with changes of average hydrodynamic diameter of mitochondria. Thus, the aim of this work was to investigate the kinetics of mitochondria diameter change under the influence of calix[4]arene chalcone amides with two and four chalcone groups, as well as to study on a primary cell culture, whether calix[4]arene chalcone amides enter the cell and whether the level of mitochondria membrane polarization is being changed after the incubation with these compounds.

\section{MATERIALS AND METHODS}

Synthesis of calix[4]arene chalcone amides was described in our previous work [10]. Structural formulas of calix[4]arene chalcone amides C- 
137, C-1012, C-1011 and C-1070 are given in Fig. 1.

Calix[4]arene chalcone amide $\mathrm{C}-137$ has two chalcone groups on a lower rim, which are distal-placed, and two free phenolic hydroxyls.

Calix[4]arene chalcone amide C-1012 has two chalcone groups, which are proximal-placed. Two other hydroxyls are replaced be propyl groups.

Calix[4]arene chalcone amide $\mathrm{C}-1011$ has four chalcone groups.

Calix[4]arene chalcone amide $\mathrm{C}-1070$ has four chalcone groups and two azophenyl groups on an upper rim.

Investigations were conducted on two biochemical models: isolated myometrium mitochondria and primary cell culture of myometrium.

Non-pregnant rat myometrium mitochondria were isolated with a differential centrifugation method [11]. The obtained sample was suspended in a solution with the following composition: $10 \mathrm{mM}$ Hepes ( $\mathrm{pH}$ 7.4), $250 \mathrm{mM}$ sucrose, $1 \mathrm{mM}$ EGTA, $0.1 \%$ bovine serum albumin. The protein concentration of the mitochondria fraction was determined by

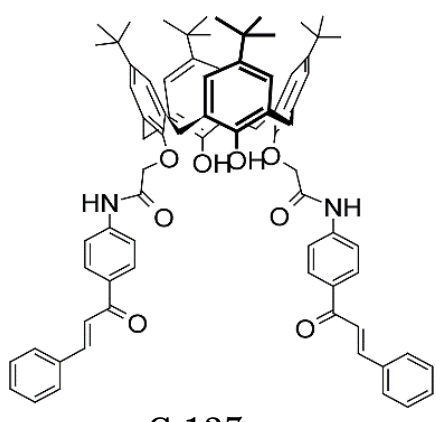

C-137

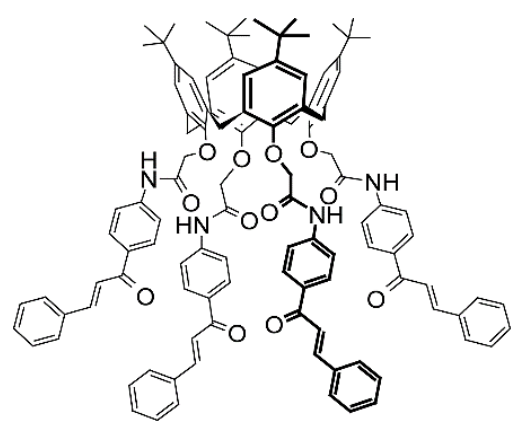

C-1011

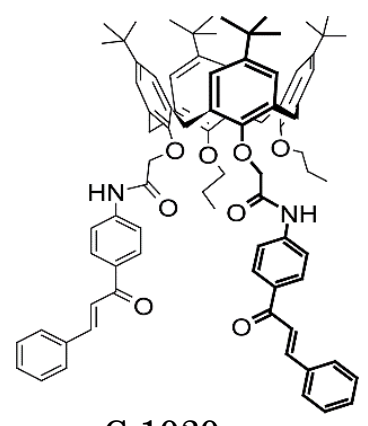

$\mathrm{C}-1020$

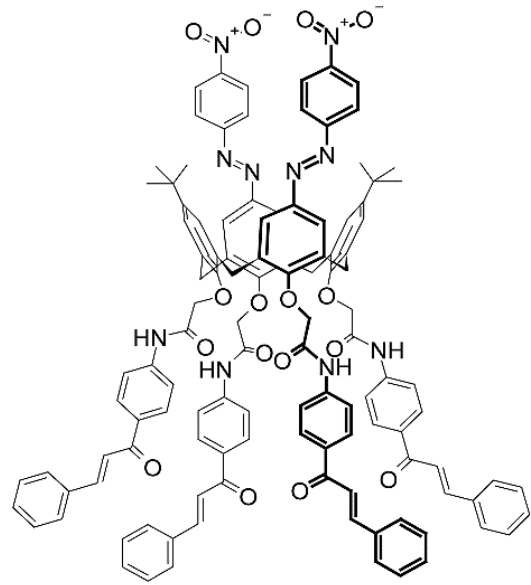

C-1070

Fig. 1. Structural formulas of calix[4]arene chalcone amides C-137, C-1012, C-1011 and C-1070. 
Bradford assay [12]. Concentration of mitochondria protein in a sample was $25 \mu \mathrm{g} / \mathrm{ml}$.

The function of mitochondria differentiation by the size was investigated with the dynamic light scattering method [13] using laser correlation spectrometer Malvern Instruments 'ZetaSizer-3' (UK) with a $\mathrm{He}-$ Ne laser LGN-111 $(P=25 \mathrm{~mW}, \lambda=663 \mathrm{~nm})$. Registration of laser emission, dispersed $(R I=1.33)$ from mitochondria suspension, was made for $30 \mathrm{sec}$ with a temperature $+22^{\circ} \mathrm{C}$ and a dispersion angle $90^{\circ}$. The data was calculated using an application software PCS-Size mode v1.61.

Myocyte suspension was isolated from non-pregnant rat myometrium with collagenase method [14]. Isolated cells were suspended in Hank's solution (without salts of $\mathrm{Mg}$ and $\mathrm{Ca}$ ) with a following composition: $136.9 \mathrm{mM} \mathrm{NaCl}, 5.36 \mathrm{mM} \mathrm{KCl}, 0.44 \mathrm{mM} \mathrm{KH}_{2} \mathrm{PO}_{4}, 4.5 \mathrm{mM} \mathrm{NaHCO}, 0.26$ $\mathrm{mM} \mathrm{Na} \mathrm{HPO}_{4}, 5.5 \mathrm{mM}$ glucose, $10 \mathrm{mM}$ Hepes (pH 7.4). Calculation of cell amount was conducted using haemocytometer. Test on viability of isolated cells was made using trypan blue dye; over $95 \%$ of cells had green colouring that proves the wholeness of plasmatic membrane.

For experiments with cationic JC-1 dye, an aliquot of cell suspension with JC-1 dye $(5 \mu \mathrm{g} / \mathrm{ml})$ was put in chambers for confocal microscopy. For experiments with calix[4]arene chalcone amides C-1070, an aliquot of cell suspension with calix[4]arene chalcone amide C-1070 $(10 \mu \mathrm{M})$ was put in chambers for confocal microscopy. After attachment of cells to the glass, the chambers were washed with Hank's solution. The time of cell attachment in chambers was 120 min. During this time, cells strongly attach to the chamber surface, which can be visualized with a light microscope.

The membrane potential of mitochondria on the model of intact uterus myocytes was investigated using the confocal laser-scanning microscope LSM 510 META Carl Zeiss with modern system of data storage and image processing, and a principle of spectrum differentiation based on motorized inverted luminescent microscope. Investigations were conducted in MultiTrack mode with a detector META, which allows registering the fluorescence on a set range of wavelength. For fluorescent dye JC-1 excitation $\left(\lambda_{e x}=490 \mathrm{~nm}, \lambda_{f l}=527\right.$ and 590 $\mathrm{nm})$, the laser line with wavelength $488 \mathrm{~nm}$ of argon laser $(30 \mathrm{~mW})$ was used and fluorescence in ranges $518-550 \mathrm{~nm}$ and $572-625 \mathrm{~nm}$ was detected. The lens was Plan-Apochromat $63 x / 1.4$ Oil DIC.

Fluorescence of myometrium cells dyed with calix[4]arene chalcone amide was also investigated using a confocal laser-scanning microscope LSM 510 META Carl Zeiss. Fluorescence of calix[4]arene chalcone amide was excited with diode laser $(30 \mathrm{~mW}, \lambda=405 \mathrm{~nm})$. For registering the fluorescence, an emission filter LP 420 was used.

Absorption spectrum of calix[4]arene chalcone amide $\mathrm{C}-1070$ was registered on spectrometer $\mathrm{CF}-2000$.

Fluorescence spectrum of calix[4]arene chalcone amide C-1070 was 
registered on spectrofluorimeter QuantaMaster ${ }^{\mathrm{TM}} 40$ by Photon Technology International.

In the study, the following reagents were used: EGTA, Hepes, D-(+)sucrose, ATP (by 'Sigma', USA), cationic dye JC-1 (by 'Invitrogen', USA), and other chemicals of domestic production of analytical or reagent grades.

\section{RESULTS AND DISCUSSIONS}

In the previous work, it was shown that incubation of mitochondria with calix[4]arene chalcone amides led to a diameter change of mitochondria: mitochondria average hydrodynamic diameter was decreasing after incubation with calix[4]arene chalcone amides C-1012, C1021, and C-1023, and was increasing after incubation with C-1011 [10]. This time we aimed to investigate the kinetics of the calix[4]arene chalcone amides with 2 and 4 chalcone groups influence on the diameter of myometrium mitochondria. Studies were made in $\mathrm{Mg}^{2+}$ - and $\mathrm{Mg}^{2+}$, ATP-containing solutions. Earlier, we have shown that general $\mathrm{Ca}^{2+}$ accumulative activity of myometrium mitochondria in $\mathrm{Mg}^{2+}$, ATP-containing solution was higher than in $\mathrm{Mg}^{2+}$ solution [15].

As it can be seen from the results in Fig. 2, hydrodynamic diameter of mitochondria (control) was higher after incubation in $\mathrm{Mg}^{2+}$ -

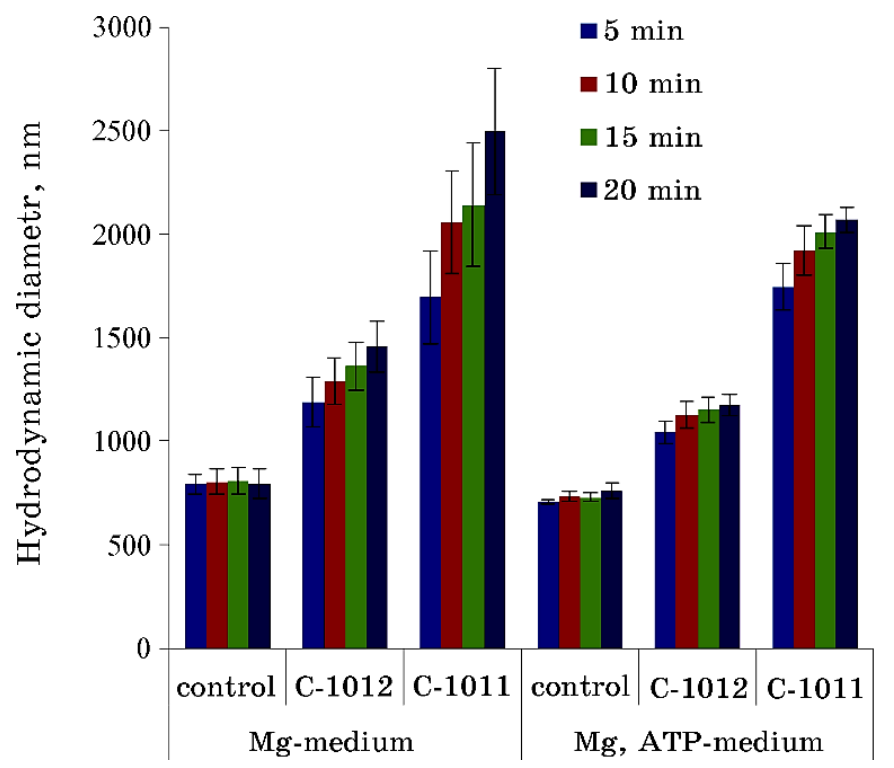

Fig. 2. Kinetics of the calix[4]arene chalcone amide's C-1012 and C-1011 influence on hydrodynamic diameter of myometrium mitochondria. $M \pm m$, $n=5$. 
containing solutions in comparison with $\mathrm{Mg}^{2+}$, ATP-containing solution. Although this number almost did not change after incubation in both solutions for $20 \mathrm{~min}$. Incubation of mitochondria with $10 \mu \mathrm{M}$ calix[4]arene chalcone amides C-1012 and C-1011 for 20 min was accompanied with an increasing of hydrodynamic diameter of mitochondria in comparison with control. Calix[4]arene chalcone amide C-1011 (four chalcone groups) had a bigger impact on size change of mitochondria in comparison with both control and calix[4]arene C-1012 (two chalcone groups). It is worth to mention that the influence of studied calix[4]arenes on mitochondria diameter also depends on the solution of incubation: in absence of ATP, the hydrodynamic diameter was higher after both incubations with C-1012 and C-1011.

Thus, mentioned results show that: 1) hydrodynamic diameter of mitochondria depends on the incubation solution, and in presence of ATP, it is smaller than in its absence; 2) hydrodynamic diameter of mitochondria lifts with time after mitochondria incubation with calix[4]arene chalcone amides; 3 ) an effect of calix[4]arene chalcone amides on hydrodynamic diameter of mitochondria goes up with an increase of chalcone groups amount in the structure of calix[4]arene; 4) an effect of calix[4]arene chalcone amides on hydrodynamic diameter of mitochondria depends on the incubation solution, and in presence of ATP, it is smaller than in its absence.

On the one hand, a change of mitochondria volume can significantly influence its physiology [16]. On the other hand, an increase of mitochondria hydrodynamic diameter can be an indicator of mitochondria swelling, which happens during depolarization. So, further investigations were directed to study the kinetics of calix[4]arene chalcone amide's influence on mitochondria membrane polarization.

In previous works, we have shown that calix[4]arene chalcone amides, after short incubation with permeabilized myometrium cells, are able to hyperpolarize mitochondria membrane [2,3]. The experiments were conducted on flow cytometer using a potential sensitive dye TMRM. This time effects of calix[4]arenes on mitochondria membrane polarization were studied with confocal microscopy on intact myometrium cells, which were loaded with cationic dye JC-1. Nevertheless, before investigating this question, we had to be sure that calix[4]arene chalcone amides are entering cells. That is why calix[4]arene C-1070 was synthesized. It is an analogue of C-1011, so it contains four chalcone groups and two azophenyl groups on an upper rim. Chromogenic azo aromatic compounds are often added to calixarene for getting dyed and fluorescent compounds [17, 18]. Using spectrophotometer, we studied the absorption spectrum of synthesized calix[4]arene. As it can be seen on the results shown in Fig. 3, we have a domed dependency graph of absorption and wavelength with maximum at $330 \mathrm{~nm}$.

After that, using spectrofluorimeter, we recorded a fluorescence 


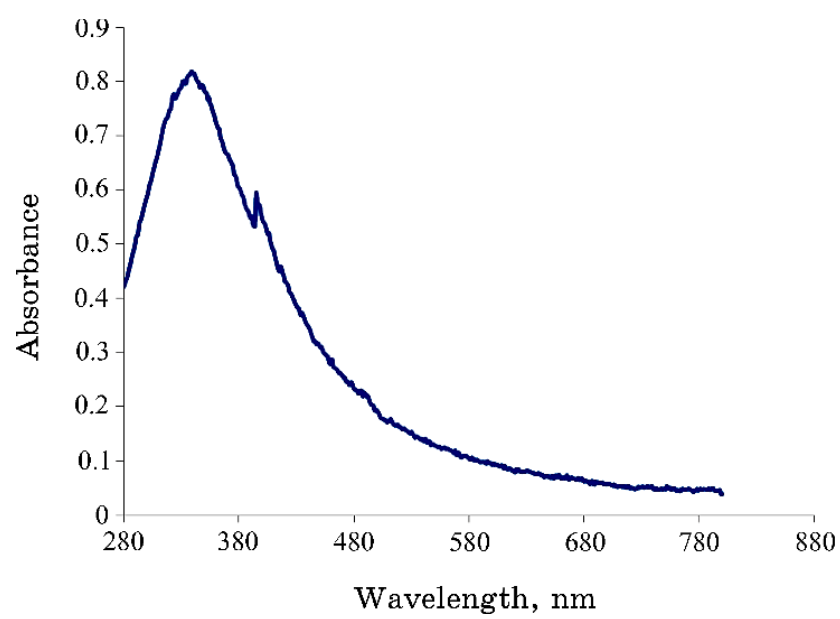

Fig. 3. Spectrum of absorption of calix[4]arene chalcone amide C-1070.

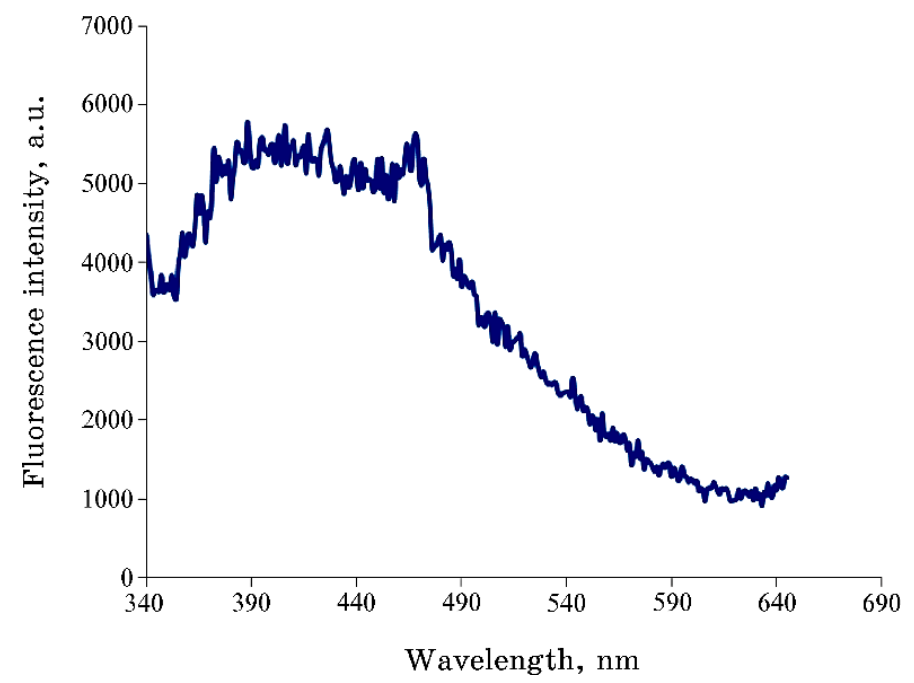

Fig. 4. Fluorescence spectrum of calix[4]arene chalcone amide C-1070, $\lambda_{e x}=330$ нм.

spectrum of calix[4]chalcone amide C-1070 at excitation wavelength $330 \mathrm{~nm}$. As shown in Fig. 4, an increase of fluorescence intensity can be registered at wavelength range $350-450 \mathrm{~nm}$.

Thus, calix[4]arene chalcone amide C-1070, which is an analogue of C-1011, can fluorescent at excitation wavelength of $330 \mathrm{~nm}$.

Further experiments were directed to study whether calix[4]arene chalcone amides enter cells. Dyed with calix[4]arene chalcone amide C1070 myometrium cells were analysed using confocal microscope. As it can be seen in Fig. 5, control cells have a low level of autofluorescence; 

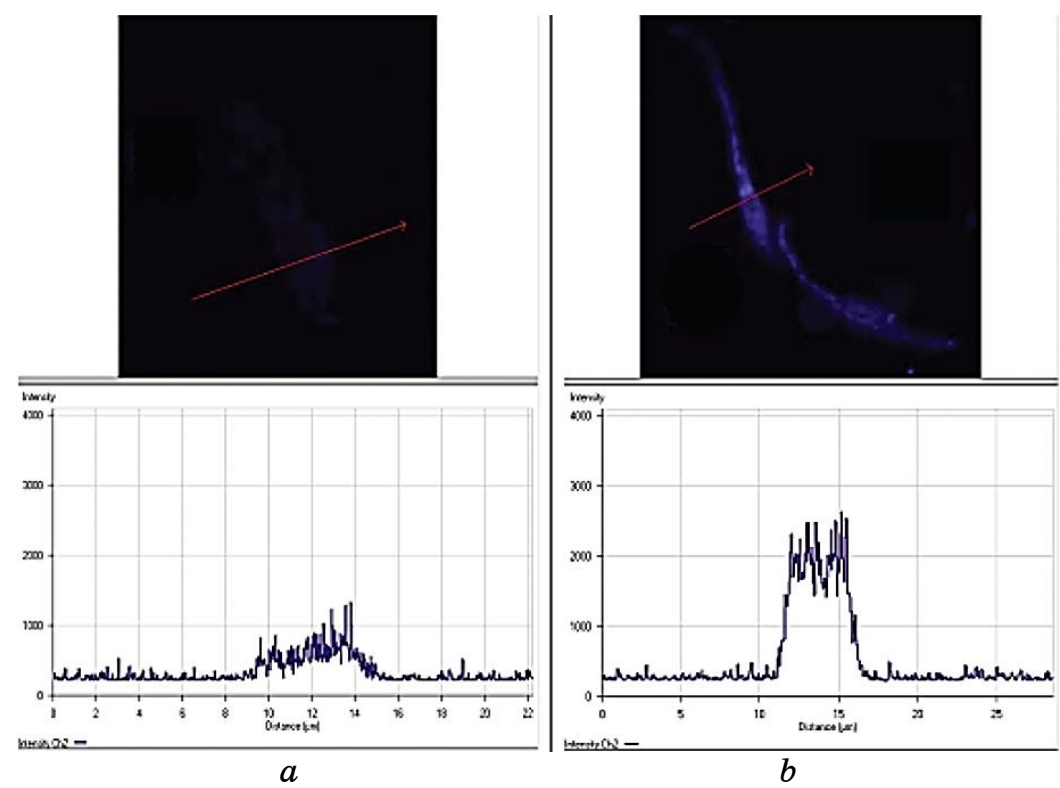

Fig. 5. Myometrium cells dyed with calix[4]arene chalcone amide C-1070: $a$ - control cells; $b$ - cells dyed with calix[4]arene chalcone amide C-1070. Typical result is presented, $n=5$.

fluorescence intensity along the randomly drawn line is not higher than 1000 relative units. At the same time, the fluorescence intensity of cells dyed with calix[4]arene chalcone amide C-1070 is couple of times higher than the one registered for control cells. Thus, calix[4]arene chalcone amides can enter the myometrium cells.

In previous works, we investigated effects of calix[4]arene chalcone amides on membrane potential of myometrium permeabilized cells mitochondria using flow cytometer and potential sensitive dye TMRM [2, 3]. Taking into consideration that calix[4]arene chalcone amides enter cells, we investigated the effects of these compounds on myometrium primary cell culture using confocal microscopy and cationic dye JC-1. JC-1 is a cationic dye, which accumulates in mitochondria depending on mitochondria's polarization level.

For excitation of JC-1 fluorescence, the laser with the same as for TMRM wavelength $490 \mathrm{~nm}$ is used. However, in comparison with TMRM, the level of mitochondria membrane polarization influences the aggregation of dye molecules: at the low polarization level an increase of fluorescence intensity in green region of spectrum $(525 \mathrm{~nm})$ is being registered; at the high polarization level J-aggregates of dye are being formed and the fluorescence intensity is being increased in red region of spectrum $(590 \mathrm{~nm})[19,20]$. Changes in the ratio of red 


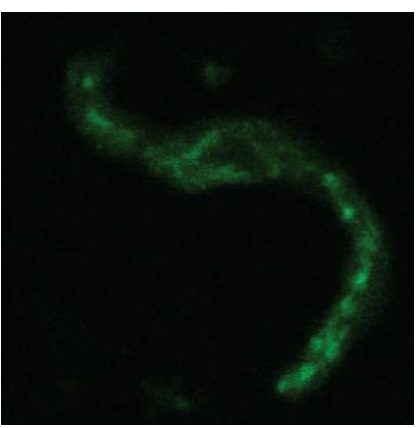

$a$

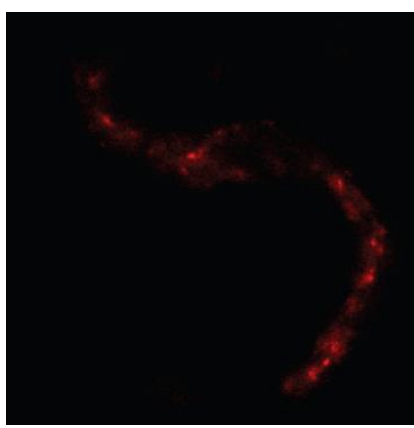

$b$

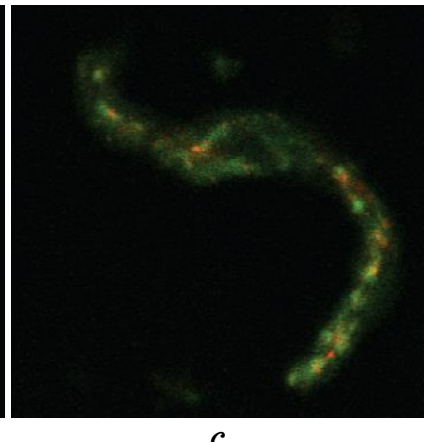

Fig. 6. Intact myometrium cells, loaded with JC-1 dye (section $a$ and $b-$ fluorescence signal in green and red regions of spectrum; section $c-$ cumulative fluorescence in both green and red regions of spectrum). Typical result is presented, $n=5$.

and green fluorescence of JC-1 dye indicate the change of mitochondria-membrane polarization level and do not depend on other factors, which can influence the signal of dye with one wavelength, like size of mitochondria, its shape and density $[19,20]$.

Therefore, we have intact myometrium cells with JC-1 dye. In Figure 6 , myometrium cells with JC-1 dye are presented. Fluorescent signal is being registered in both the green region of the spectrum (Fig. 6, $a$ ) and the red region (Fig $6, b$ ), which shows the presence of mitochondria in myometrium cells with different membrane polarization level of these organelles (section $c$ demonstrates cumulative fluorescence in the green and red regions of the spectrum).

After that, we investigated the effects of calix[4]arene chalcone amide C-137 on mitochondria membrane potential. Loaded with JC-1 dye myometrium cells were incubated with calix[4]arene chalcone amides $\mathrm{C}-137(10 \mu \mathrm{M})$ for $20 \mathrm{~min}$. Mitochondria membrane potential $(P)$ was analysed by the ratio of fluorescence intensity in the red region of a spectrum to the one in green region. As it can be seen in Fig. 7, the dependence graph of $P$ and $t$ had linear or domed nature. Earlier, we have shown that a short incubation of myometrium cells perforated with digitonin in $10 \mu \mathrm{M}$ C-137 was accompanied with hyperpolarization of mitochondria membrane [2]. It should be also mentioned that, in these experiments, the incubation solution had $(2-2.5) \cdot 10^{5} / \mathrm{ml}$ myometrium cells. Nevertheless, a fewer amount of cells are attached to the confocal chamber glass that results into a different ratio of calix[4]arene chalcone amides C-137:cell. In the first case (Fig. 7a), we succeeded in registering a phase of $P$ increasing, which shows the mitochondria membrane hyperpolarization. The further incubation was accompanied with decreasing of $P$, which shows the depolarization. In Figure 7, $b$, 

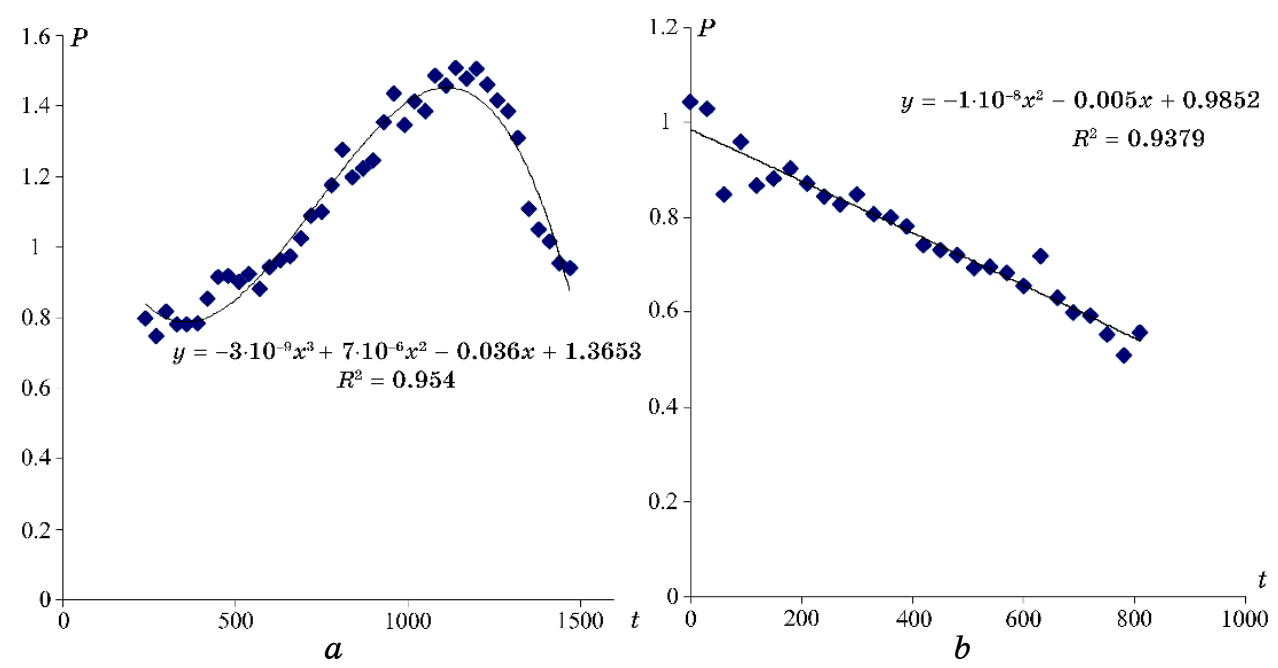

Fig. 7. Kinetics of calix[4]arene chalcone amide C-137 influence on myometrium mitochondria. Ordinate axis shows the ratio between the fluorescence intensity in red region of spectrum to the fluorescence intensity in green region $(P)$; abscissa axis shows the time of incubation in $\sec (t)$.

hyperpolarization was not registered, just the depolarizing effect of calix[4]arene chalcone amide $\mathrm{C}-137$ on myometrium mitochondria is shown ( $P$ decreases linearly over time).

Hyperpolarization of mitochondria membrane is known to be a first stage on the way to depolarization, which leads to cells death [21]. Chalcones belong to the substances, which facilitate the triggering of apoptosis with the mitochondrial path [22]. On the isolated rat hepatocytes, it was shown that cytotoxic effect of hydroxychalcones could be explained with the collapse of mitochondria membrane potential [23]. Thus, mitochondria, whose main role is providing cells with energy, can facilitate an apoptosis development in some cases that is to cause a cell death. Participation of mitochondria in apoptosis is a reason to search for compounds, which will facilitate death of unwanted cells. Medical statistics proclaims that uterine fibroids are a widely spread pathology. Looking for compounds, which would be able to activate processes of triggering an apoptosis with the participation of mitochondria that can lead to a decrease of fibroids size and possible relief of symptoms [24], is very important.

Therefore, we have shown that mitochondria incubation with calix[4]arene chalcone amides for 20 min was accompanied with an increase of an average hydrodynamic diameter of mitochondria, which correlates with depolarizing effect of calix[4]arene chalcone amide C137 on myometrium intact cells. 


\section{ACKNOWLEDGEMENTS}

The authors acknowledge Ch. Kurytsia and D. Tsapok for taking part in conducting the experiments.

The work was made with the support of grants of targeted complex program of fundamental studies of the N.A.S. of Ukraine 'Fundamental problems of creating new nanomaterial and nanotechnologies' (No. of governmental registration 0115U003638) and targeted complex interdisciplinary program of scientific investigation of the N.A.S. of Ukraine 'Molecular and cell biotechnologies for needs of medicine, industry and agriculture' (No. of governmental registration 0115U003639).

\section{REFERENCES}

1. R. Rodik, V. Boiko, O. Danylyuk, K. Suwinska, I. Tsymbal, N. Slinchenko, and V. Kalchenko, Tetrahedron Letters, 46, No. 43: 7459 (2005); https://doi.org/10.1016/j.tetlet.2005.07.069.

2. L. G. Babich, S. G. Shlykov, V. I. Boĭko, M. A. Kliachina, and S. A. Kosterin, Bioorganicheskaya Khimiya, 39, No. 6: 728 (2013).

3. L. G. Babich, S. G. Shlykov, A. M. Kushnarova, O. A. Esypenko, and S. O. Kosterin, Nanosistemi, Nanomateriali, Nanotehnologii, 15, No. 1: 193 (2017) (in Ukrainian); https://doi.org/10.15407/nnn.15.01.0193.

4. D. Shetty, I. Jahovic, J. Raya, Z. Asfari, J.-C. Olsen, and A. Trabolsi, ACS Appl. Mater. Interfaces, 10, No. 3: 2976 (2018); https://doi.org/10.1021/acsami.7b16546.

5. A. J. Leyn-González, N. Acero, D. Mucoz-Mingarro, I. Navarro, and C. Martín-Cordero, Current Medicinal Chemistry, 22, No. 30: 3407 (2015).

6. $\quad$ D. K. Mahapatra and S. K. Bharti, Life Sciences, 148: 154 (2016); https://doi.org/10.1016/j.lfs.2016.02.048.

7. B. Orlikova, D. Tasdemir, F. Golais, M. Dicato, and M. Diederich, Genes and Nutrition, 6, No. 2: 125 (2011); https://doi.org/10.1007/s12263-011-0210-5.

8. S. Zhang, T. Li, Y. Zhang, H. Xu, Y. Li, X. Zi, and H.-M. Liu, Toxicology and Applied Pharmacology, 309: 77 (2016); https://doi.org/10.1016/j.taap.2016.08.023.

9. B. Zhou and C. Xing, Medicinal Chemistry, 5, No. 8: 388 (2015); https://doi.org/10.4172/2161-0444.1000291.

10. S. G. Shlykov, A. M. Kushnarova-Vakal, A. V. Sylenko, L. G. Babich, O. Y. Chunikhin, O. A. Yesypenko, and S. O. Kosterin, Ukr. Biochem. J., 91, No. 3: 46 (2019); https://doi.org/10.15407/ubj91.03.046.

11. S. A. Kosterin, N. F. Bratkova, and M. D. Kurskiū, Biokhimiya, 50, No. 8: 1385 (1985).

12. M. M. Bradford, Analytical Biochemistry, 72: 248 (1976).

13. H. G. Merkus, Particle Size Measurements - Fundamentals, Practice, Quality (Springer Netherlands: 2009).

14. P. Mollard, J. Mironneau, T. Amedee, and C. Mironneau, The American Journal of Physiology, 250: No. 1: 47 (1986). 
15. L. G. Babich, S. G. Shlykov, A. M. Kushnarova-Vakal, N. I. Kupynyak, V. V. Manko, V. P. Fomin, and S. O. Kosterin, Ukr. Biochem. J., 90, No. 3: 32 (2018); https://doi.org/10.15407/ubj90.03.032.

16. K. Nowikovsky, R. J. Schweyen, and P. Bernardi, BBA-Bioenergetics, 1787, No. 5: 345 (2009); https://doi.org/10.1016/j.bbabio.2008.10.006.

17. H. Halouani, I. Dumazet-Bonnamour, and R. Lamartine, Tetrahedron Letters, 43: 3785 (2002).

18. Ö. Karakus and H. Deligöz, J. Incl. Phen., 61: 289 (2008).

19. S. T. Smiley, M. Reers, C. Mottola-Hartshorn, M. Lin, A. Chen, T. W. Smith, and L. B. Chen, Proceedings of the National Academy of Sciences of the United States of America, 88, No. 9: 3671 (1991).

20. S. Salvioli, A. Ardizzoni, C. Franceschi, and A. Cossarizza, FEBS Letters, 411, No. 1: 77 (1997).

21. T. H. Sanderson, C. A. Reynolds, R. Kumar, K. Przyklenk, and M. Hüttemann, Molecular Neurobiology, 47, No. 1: 9 (2013); https://doi.org/10.1007/s12035-012-8344-z.

22. R. M. P. Gutierrez, A. Muniz-Ramirez, and J. V. Sauceda, African Journal of Pharmacy and Pharmacology, 9, No. 8: 237 (2015); https://doi.org/10.5897/ajpp2015. 4267.

23. O. Sabzevari, G. Galati, M. Y. Moridani, A. Siraki, and P. J. O’Brien, Chemico-Biological Interactions, 148, Nos. 1-2: 57 (2004); https://doi.org/10.1016/j.cbi.2004.04.004.

24. Z.-P. Cheng, X. Tao, J. Gong, H. Dai, L.-P. Hu, and W.-H. Yang, European Journal of Obstetrics, Gynecology, and Reproductive Biology, 145, No. 1: 113 (2009); https://doi.org/10.1016/j.ejogrb.2009.03.027. 